\title{
Multiscale Sagebrush Rangeland Habitat Modeling in the Gunnison Basin of Colorado
}

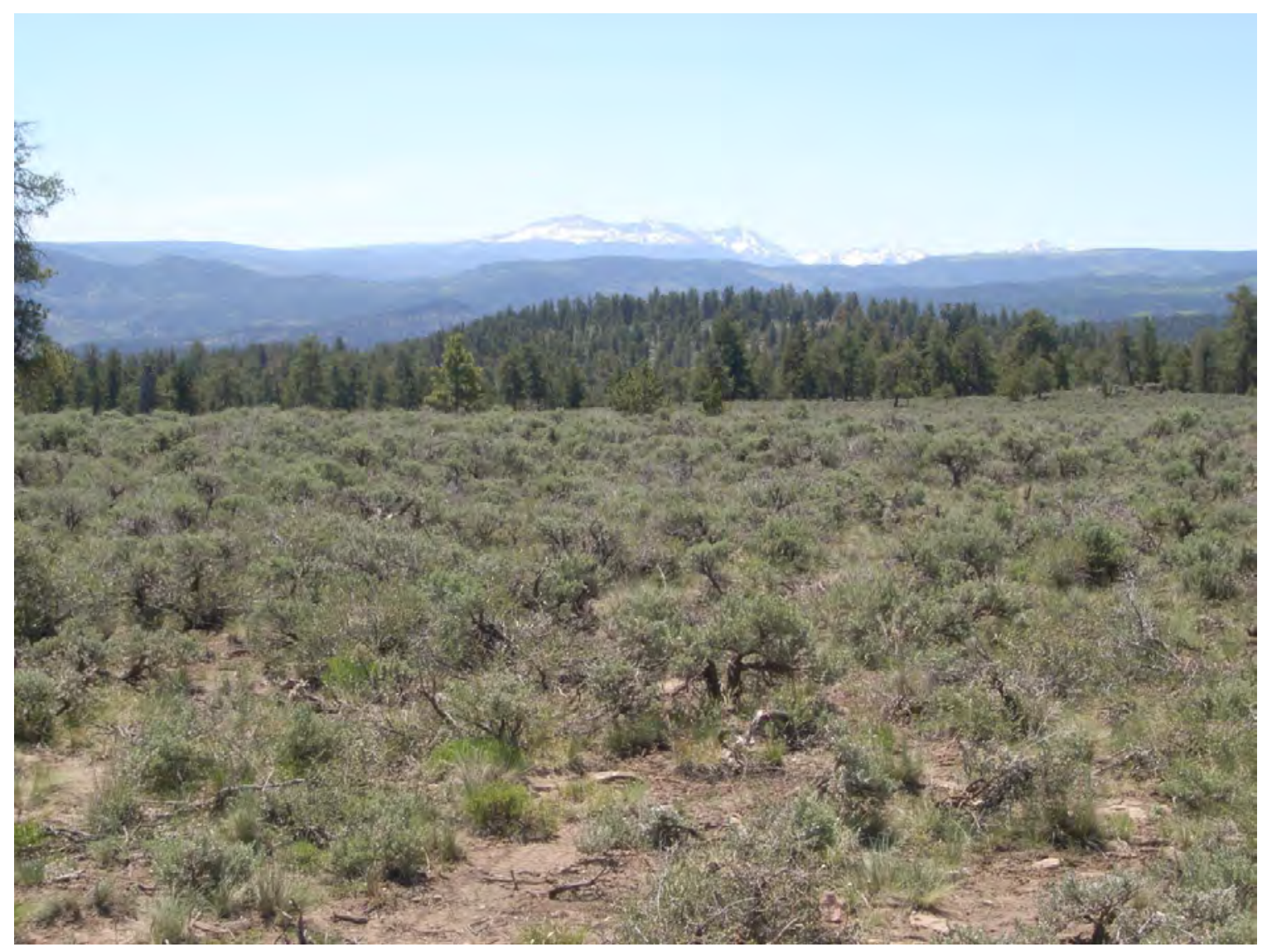

Open-File Report 2013-1049 
Cover photograph. "Main Gulch” in Gunnison Basin, Colorado, 2007 (photograph by Lorie Brummer, U.S. Geological Survey). 


\section{Multiscale Sagebrush Rangeland Habitat Modeling in the Gunnison Basin of Colorado}

By Collin G. Homer, Cameron L. Aldridge, Debra K. Meyer, and Spencer J. Schell

Open-File Report 2013-1049 


\title{
U.S. Department of the Interior SALLY JEWELL, Secretary
}

\section{U.S. Geological Survey Suzette M. Kimball, Acting Director}

\author{
U.S. Geological Survey, Reston, Virginia: 2013
}

For more information on the USGS - the Federal source for science about the Earth, its natural and living resources, natural hazards, and the environment, visit http://www.usgs.gov or call 1-888-ASK-USGS.

For an overview of USGS information products, including maps, imagery, and publications, visit http://www.usgs.gov/pubprod

To order this and other USGS information products, visit http://store.usgs.gov

Any use of trade, firm, or product names is for descriptive purposes only and does not imply endorsement by the U.S. Government.

Although this information product, for the most part, is in the public domain, it also may contain copyrighted materials as noted in the text. Permission to reproduce copyrighted items must be secured from the copyright owner.

Suggested citation:

Homer, C.G., Aldridge, C.L., Meyer, D.K., and Schell, S.J., 2013, Multiscale sagebrush rangeland habitat modeling in the Gunnison Basin of Colorado: U.S. Geological Survey Open-File Report 2013-1049, 12 p., http://pubs.usgs.gov/ of/2013/1049/. 


\section{Contents}

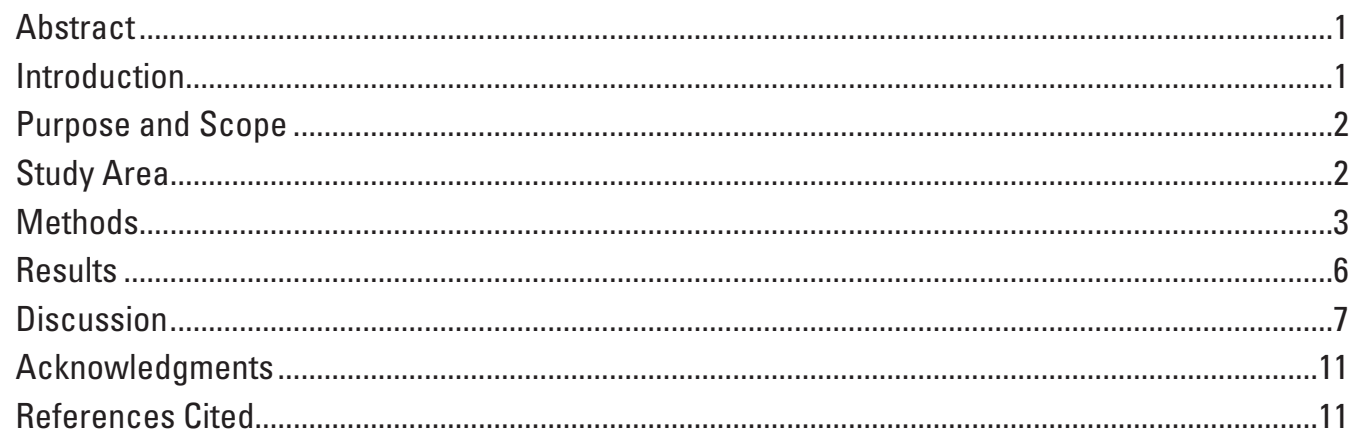

\section{Figures}

1. Map showing location and spatial extent of the study areas for mapping sagebrush habitats in south-central Colorado in 2007.

2. Field protocol design for sampling sagebrush rangeland components using 14 quadrats within each sampled polygon.

3. Map showing location of the 41 sagebrush rangeland accuracy assessment plots across the Landsat path 34 row 33 study area focused on the Gunnison Basin, Colorado

4. Example of percent bare ground predictions at two spatial scales, in QuickBird site 1 within the Gunnison Basin, Colorado.

5. Example predictions for four primary sagebrush rangeland components from QuickBird imagery in QuickBird site 1 within the Gunnison Basin, Colorado ....................8

6. Example predictions for four primary components from Landsat (30-meter) imagery in the Gunnison Basin, Colorado..

\section{Tables}

1. Input layer number and type used to model components .................................................

2. Comparison of QuickBird acquisitions versus field sampling dates..................................6

3. Accuracy assessment (AA) of all sagebrush rangeland variable predictions for each study area extent and sensor, from south-central Colorado. 


\section{Conversion Factors and Datums}

SI to Inch/Pound

\begin{tabular}{lcl}
\hline \multicolumn{1}{c}{ Multiply } & By & \multicolumn{1}{c}{ To obtain } \\
\hline centimeter $(\mathrm{cm})$ & Length & \\
meter $(\mathrm{m})$ & 0.3937 & inch (in.) \\
kilometer $(\mathrm{km})$ & 3.281 & foot (ft) \\
\hline & 0.6214 & mile (mi) \\
\hline square meter $\left(\mathrm{m}^{2}\right)$ & Area & acre \\
hectare $($ ha) & 0.0002471 & acre \\
square kilometer $\left(\mathrm{km}^{2}\right)$ & 2.471 & acre \\
square meter $\left(\mathrm{m}^{2}\right)$ & 247.1 & square foot $\left(\mathrm{ft}^{2}\right)$ \\
hectare $($ ha) & 10.76 & square mile $\left(\mathrm{mi}^{2}\right)$ \\
square kilometer $\left(\mathrm{km}^{2}\right)$ & 0.003861 & square mile $\left(\mathrm{mi}^{2}\right)$ \\
\hline
\end{tabular}

Temperature in degrees Celsius $\left({ }^{\circ} \mathrm{C}\right)$ may be converted to degrees Fahrenheit $\left({ }^{\circ} \mathrm{F}\right)$ as follows:

${ }^{\circ} \mathrm{F}=\left(1.8 \times^{\circ} \mathrm{C}\right)+32$

Vertical coordinate information is referenced to the North American Vertical Datum of 1988 (NAVD 88).

Horizontal coordinate information is referenced to the North American Datum of 1983 (NAD 83). 


\title{
Multiscale Sagebrush Rangeland Habitat Modeling in the Gunnison Basin of Colorado
}

\author{
By Collin G. Homer' ${ }^{1}$, Cameron L. Aldridge ${ }^{2}$, Debra K. Meyer ${ }^{3}$, and Spencer J. Schell ${ }^{1}$
}

\section{Abstract}

North American sagebrush-steppe ecosystems have decreased by about 50 percent since European settlement. As a result, sagebrush-steppe dependent species, such as the Gunnison sage-grouse, have experienced drastic range contractions and population declines. Coordinated ecosystem-wide research, integrated with monitoring and management activities, is needed to help maintain existing sagebrush habitats; however, products that accurately model and map sagebrush habitats in detail over the Gunnison Basin in Colorado are still unavailable. The goal of this project is to provide a rigorous large-area sagebrush habitat classification and inventory with statistically validated products and estimates of precision across the Gunnison Basin. This research employs a combination of methods, including (1) modeling sagebrush rangeland as a series of independent objective components that can be combined and customized by any user at multiple spatial scales; (2) collecting ground measured plot data on 2.4-meter QuickBird satellite imagery in the same season the imagery is acquired; (3) modeling of ground measured data on 2.4-meter imagery to maximize subsequent extrapolation; (4) acquiring multiple seasons (spring, summer, and fall) of Landsat Thematic Mapper imagery (30-meter) for optimal modeling; (5) using regression tree classification technology that optimizes data mining of multiple image dates, ratios, and bands with ancillary data to extrapolate ground training data to coarser resolution Landsat Thematic Mapper; and 6) employing accuracy assessment of model predictions to enable users to understand their dependencies. Results include the prediction of four primary components including percent bare ground, percent herbaceous, percent shrub, and percent litter, and four secondary components including percent sagebrush (Artemisia spp.), percent big sagebrush (Artemisia tridentata), percent Wyoming sagebrush (Artemisia tridentata wyomingensis), and shrub height (centimeters). Results were validated with an independent accuracy assessment, with root mean square

\footnotetext{
${ }^{1}$ U.S. Geological Survey

${ }^{2}$ NREL, Colorado State University and U.S. Geological Survey

${ }^{3}$ Stinger Ghaffarian Technologies, Inc.
}

error values ranging from 3.5 (percent big sagebrush) to 10.8 (percent bare ground) at the QuickBird scale, and from 4.5 (percent Wyoming sagebrush) to 12.4 (percent herbaceous) at the full Landsat scale. These results offer significant improvement in sagebrush ecosystem quantification across the Gunnison Basin, and also provide maximum flexibility to users to employ for a wide variety of applications. Further refinement of these remote sensing component predictions in the future will be most likely achieved by focusing on more extensive ground plot sampling, employing new high and moderate-resolution satellite sensors that offer additional spectral bands for vegetation discrimination, and capturing more dates of satellite imagery to better represent phenological variation.

\section{Introduction}

Sagebrush ecosystems are important for sustaining a variety of landscape functions and provide vital ecological, hydrological, biological, agricultural, and recreational ecosystem services in arid and semiarid areas in the intermountain region of the western United States (Connelly and others, 2004; Davies and others, 2007; Anderson and McCuistion, 2008). However, North American sagebrush-steppe ecosystems have decreased by about 50 percent since European settlement (Schroeder and others, 2004). Habitat loss and fragmentation due to urban development, associated infrastructure, and conversion of habitats to other uses (Oyler-McCance and others, 2001; Aldridge and others, 2012), has caused sagebrushsteppe dependent species such as the Gunnison sage-grouse to experiance severe population declines (Gunnison Sage-Grouse Rangewide Steering Committee, 2005) which threaten the long-term viability of the species (Gunnison Sage-Grouse Rangewide Steering Committee, 2005; Aldridge and others, 2012)

Gunnison sage-grouse (C. minimus) is the smaller of the two sage-grouse species, whose geographic distribution is limited to southwestern Colorado and southeastern Utah (Schroeder and others, 2004). There are an estimated 4,000 birds remaining, distributed across 7 disjunction populations (GSGRSC, 2005; Aldridge and others, 2012). Approximately 87 percent of birds are contained within the largest population, 
located in the Gunnison Basin of Colorado (Aldridge and others, 2012). In 2010, Gunnison sage-grouse were considered a candidate species under the U.S. Endangered Species Act (65 Federal Register 82310). Threats to species persistence, such as those for greater sage-grouse (C. urophasianus), include loss and degradation of habitats, especially as it relates to increasing human population growth within the area (Colorado Water Conservation Board, 2009; Aldridge and others, 2012). To ensure long-term persistence of this species, there is a need to quantify and monitor sagebrush habitats across the basin, allowing for best management practices to be identified and the spatial identification and protection of crucial resources on the landscape. Currently, such products do not exist for the basin, but have recently been developed for other regions. (Homer and others, 2008; Homer and others, 2012).

Currently, remote sensing offers the best data source to both efficiently and effectively characterize sagebrush landscapes across the range of spatial and temporal scales in the Gunnison Basin. Traditional remote sensing products in this region have attempted only a category based approaches, using generalized land cover or vegetation cover-type classes for delineation (Rollins, 2009; Schrupp and others, 2000). This more subjective approach can be adequate for general applications, but quickly breaks down when the attempt is made to either broaden the use or repeat the process. Recent advances in remote sensing modeling and mapping of rangeland vegetation characteristics using multi-scale resolution imagery now allow for more objective continuous cover component predictions to be made across large regions like the Gunnison Basin at 30-meter (m) resolution (Homer and others, 2008; Homer and others, 2012). This new approach also provides an improved foundation for monitoring and habitat characterization over traditional products, and would represent a useful tool for land and wildlife resource managers within the Gunnison Basin. Subsequently, we developed a continuous field method of sagebrush habitat component assessment to improve source products for sage-grouse habitat characterization across the Gunnison Basin.

\section{Purpose and Scope}

The goal of this project was to develop a rigorous habitat characterization that provides statistically validated products with estimates of precision for quantifying habitat components of the sagebrush ecosystem across the entire Gunnison Basin, Colorado. A combination of approaches was used to characterize sagebrush rangelands, expanding beyond traditional remote sensing methods (Homer and others, 2012). This combination includes (1) modeling rangeland as a series of independent objective components that can be synergistically customized by any user at multiple spatial scales; (2) collecting ground measured plot data on 2.4-m QuickBird (QB) satellite imagery in the same season the imagery is acquired; (3) effective modeling of ground measured data on 2.4-m imagery to maximize subsequent extrapolation; (4) acquiring multiple seasons (spring, summer, and fall) of Landsat Thematic Mapper (TM) imagery (30-m) for optimal modeling; (5) using regression tree classification technology that optimizes data mining of multiple image dates, ratios, and bands with ancillary data to extrapolate ground training data to a coarser resolution sensor (Homer and others, 2012); and 6) employing accuracy assessment of model predictions to enable users to understand their dependencies.

Specific objectives included:

1. Develop, measure, and assess field sample protocols that support collection of training and testing (evaluation) data for optimal remote sensing predictions at two spatial scales.

2. Develop, predict, and assess eight rangeland components (including percent bare ground, percent shrub, percent herbaceous, percent litter, percent sagebrush, percent big sagebrush, percent Wyoming sagebrush, and shrub height) across four 64-kilometer-squared $\left(\mathrm{km}^{2}\right)$ study sites using 4-m QB imagery.

3. Develop, predict, and assess the extrapolation of 4-m QB predictions of eight rangeland components across the entire Gunnison Basin in Colorado using 30-m Landsat TM imagery.

\section{Study Area}

The operational scale of the study is the full extent of the Landsat TM scene, encompassing World Reference System-2 path 34, row 33 (hereafter called 34/33), which falls in central Colorado (fig. 1). The focus was on the Gunnison Basin, an approximately $845-\mathrm{km}^{2}$ area in the southwest corner of the scene. The basin is a high-elevation valley on the eastern side of the Colorado plateau, with elevations ranging from 2,180 to $3,100 \mathrm{~m}$. The average annual temperature and precipitation are 3.1 degrees centigrade and 27 centimeters, respectively. Sagebrush-steppe is common across the basin, with big sagebrush (Artemisia tridentata) being the dominant species. Narrowleaf cottonwood (Populus angustifolia), juniper (Juniperus scopulorum), gamble oak (Quercus gambelii), serviceberry (Amelanchier alnifolia) and wild rose (Rosa woodsii) occur in the riparian areas and drainages. Most of the valley bottoms along major drainages have been converted to hayfields and pastures. High elevation areas contain forests of ponderosa pine (Pinus ponderosa), Douglas fir (Pseudotsuga menziesii), spruce (Picea spp.), and aspen (Populus tremuloides).

Prediction results are reported across four analyzed 64- $\mathrm{km}^{2} \mathrm{QB}$ ) scenes (QB sites 1-4), which were placed across the Gunnison Basin and provided a typical range of expected sagebrush habitat types and conditions. Prediction results also are reported for the entire 34/33 Landsat scene, excluding 


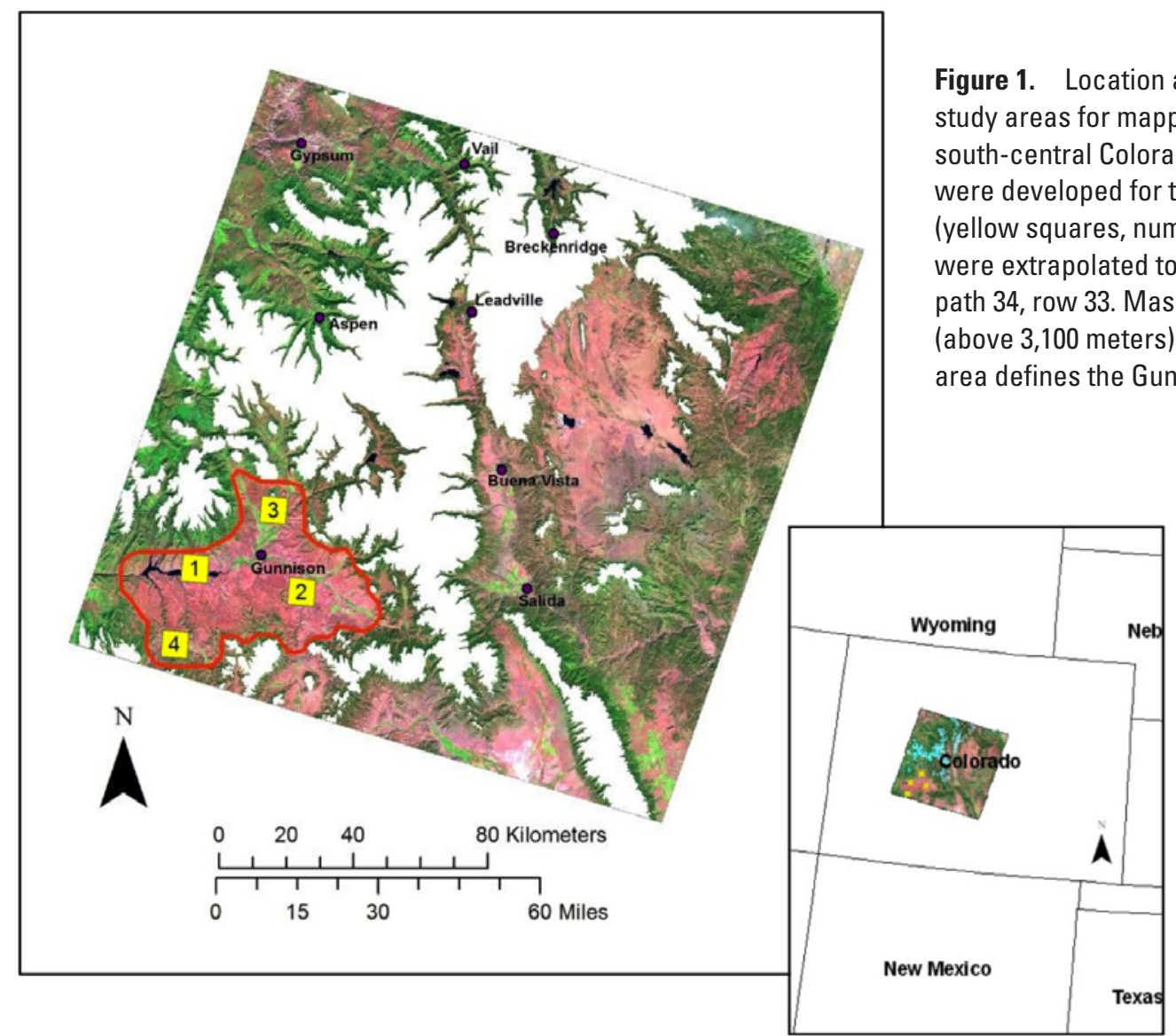

areas more than 3,100-m in elevation. The full Landsat scene study area provided an opportunity to test the accuracy of predictions scaled up from the QuickBird scale to the Landsat scale under scenarios typical of future full scale operational products.

\section{Methods}

Methods were developed to combine 2.4-m QB and 30-m Landsat TM imagery with rigorous ground sampling to produce continuous fractional vegetation predictions (for example, the percentage of a cell or pixel covered by the component) for eight sagebrush-steppe habitat components (similar to Homer and others, 2012). The four primary components, which represent 100 percent of all cover in a habitat without trees, include percent bare ground, percent herbaceous (grasses and forbs), percent shrub, and percent litter. The four secondary components are all subsets of the shrub primary component, and include percent sagebrush (Artemisia spp.), percent big sagebrush (A. tridentata), percent Wyoming sagebrush (A. t. wyomingensis) and mean shrub height (centimeters). Specific methodological descriptions are detailed below.

Field sampling protocols: Definiens eCognition ${ }^{\circledR}$ software was used to segment QB imagery into uniform polygon patches to identify sites for potential field sampling. Each image was also per-pixel classified into 30 unsupervised clusters using an isodata algorithm in Leica Geosystems ERDAS IMAGINE $^{\circledR}$ software (similar to the method described in Homer and others, 2009). Segmented polygons were intersected with the 30 clusters to identify the majority cluster class in each polygon. Potential polygons were filtered based on the size of the patch (greater than 0.5 hectare), adjacency to roads (within $1 \mathrm{~km}$ ), land ownership (public access), and spatial distribution across the image. Typically, if available, at least two polygons from each of the 30 cluster classes were selected, with a minimum of 70 selected polygons per QB scene. This process was designed to ensure that selected samples represented the spectral and ecological diversity within the QB footprint while also facilitating the field sampling effort. Selected polygons were supplied to field crews for ground sampling as near to the QB image acquisition date as logistically possible.

The vegetation characteristics of each selected polygon were sampled at 141 -meter-squared $\left(\mathrm{m}^{2}\right)$ quadrats divided evenly between and along two $30-\mathrm{m}$ transects (fig. 2). The start point for the first transect was located in a randomly chosen ordinal north, south, east, or west direction $10 \mathrm{~m}$ from the polygon centroid. The transect was extended at a $90^{\circ}$ angle from the originally chosen direction (randomly picked from 


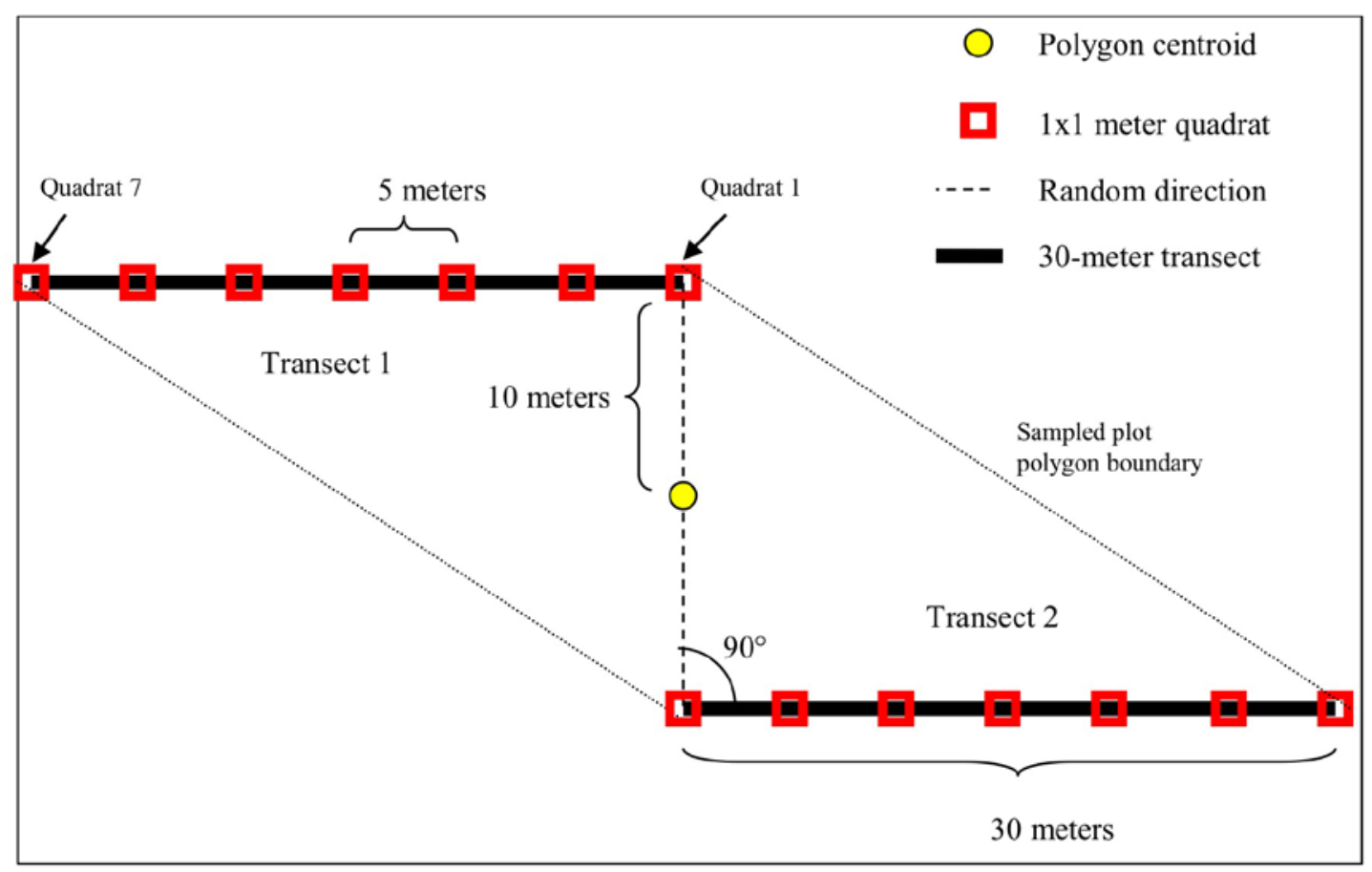

Figure 2. Field protocol design for sampling sagebrush rangeland components using 14 quadrats within each sampled polygon.

the two possibilities). Individual quadrats were placed every $5 \mathrm{~m}$ along the transect, beginning from the starting point. The second transect started $10 \mathrm{~m}$ from the polygon centroid but in the opposite direction from the first start point, and extended parallel to but in the opposite direction from the first transect (fig. 2).

Cover for each quadrat was estimated from an overhead perspective. Estimates were made in 5 percent increments, and the total of all vegetation cover components could not sum beyond 100 percent. Shrubs and trees were identified also and estimated at the species level, with sagebrush covers assessed at the sub-species level. All other components within the quadrat were combined into broad categories of herbaceous vegetation, litter, and bare ground. Cover measurements for shrubs were based on only parts of the canopy with live green vegetation. Cover measurements for herbaceous vegetation consisted of all grasses (live and residual standing) and forbs (including plants like sellaginella, phlox, and cacti). Litter was estimated as the combined cover of standing woody vegetation (including exposed shrub stems, alive or dead) and all detached plant and animal organic matter. Bare ground included any exposed soil or rocks. The height of each shrub or tree species was estimated by measuring the droop height of the tallest green vegetation (excluding seed stalks) for one representative plant within each quadrat.

For application to remotely sensed data, the mean value for each of the eight components was calculated across all 14 $1-\mathrm{m}^{2}$ quadrats within a sampled polygon. These values were assigned to all QB pixels occurring within the sampled plot, defined as a polygon connecting the start and end points of both transects.

QuickBird imagery predictions: The proportion of each of eight components occurring within all four QB footprints on a per-pixel basis was classified independently using commercial regression tree (RT) software called Cubist ${ }^{\mathbb{}}$ (Quinlan, 1993), identifying empirical relations between each component and the QuickBird data. Typically, all four 2.4-m spectral bands (bands 1-4) were used directly, with an additional three bands of ratio indices derived for capturing the Green Normalized Difference Vegetation Index [NDVI; (band 4-band 2)/(band 4+band 2)], Moisture Index [(band $4-$ band1)/(band $4+$ band 1)], and Specific Leaf Area Vegetation Index [(band 4)/(band $3+$ band 2)] bringing the total to seven input bands. Training inputs for each component were developed using the average value for each sampled plot within each QuickBird footprint (typically 55 sample plots). Predictions quantifying the spatial distribution and per-pixel proportion of seven components as a continuous variable from 0 to 100 percent and shrub height (in centimeters) were then produced for all pixels in each QuickBird image. Model fit was assessed by comparing sample training data with model predictions using a Pearson's correlation.

Landsat imagery predictions: Predictions of all eight rangeland components were classified independently for the full Landsat 34/33 study area to test procedures under operational scenarios. Each component prediction from the four QuickBird footprints (objective 2) was re-sampled from 2.4-m cells to $30-\mathrm{m}$ cells to provide training data for the Landsat model predictions. The training data were then further refined 
using a filtering model to eliminate outlier pixels (Homer and others, 2012). Only those pixels with prediction summations for the four primary components (percent bare ground, shrub, herbaceous, and litter) that ranged from 90 percent to 110 percent were retained for training. All Landsat images were corrected using the Multi Resolution Land Characteristics Consortium (MRLC) image protocol, which standardized the imagery to at-satellite reflectance before using the imagery in the modeling (Chander and others, 2009). Input layer combinations were drawn from multiple image dates, ratios that targeted spectral content, ratio differences between these dates, and ancillary topographic data. A combination of 40 input layers (table 1) was used to derive model results for the Landsat predictions. These input layers represent the total data made available to Cubist for data mining to build model predictions for each component response variable.

Because RT models are sensitive to proportional weighting of data, multiple trials were performed to determine the training data proportions required to provide the most accurate predictions. Analysis of each trial depended upon the crossvalidated model fit and visual inspection to determine the best predictions. Ultimately, we divided data for each of the eight component response variables into three roughly equal bins, defined by thresholds derived from the mean and RMSE values of predictions. Values less than the mean minus the RMSE were grouped into a low bin, values greater than the mean plus the RMSE were grouped into a high bin, and the remaining values were considered the middle bin. Because the re-sampling process inherently narrows the range of values and the RT models tend to concentrate on the most frequent values (in this case, the medium predictions in the middle bin were thinned), this approach attempted to ensure that higher and lower component predictions would carry more equal weighting in model development and reduce overall bias. Predictions were extrapolated for all 7 cover variables from 0 to 100 percent, and the shrub height variable, across all Landsat pixels in the 34/33 area. Ssecondary shrub components were reconciled (sagebrush, big sagebrush, and Wyoming sagebrush) to the primary shrub components to retain proper hierarchy, by ensuring the summation of secondary component canopy did not exceed shrub canopy and by removing any secondary shrub height value where there were 0 percent shrub estimates.

Accuracy Assessment: For QB scale predictions, an accuracy assessment evaluation was performed for the 4 QB images using 16 plots chosen from the pool of sampled plots for each image and excluded from model development. These evaluation plots were selected by targeting spectral categories (30 per image) that contained excess plots beyond the two required for model training and then randomly choosing the validation plot from the candidate plots within each targeted spectral category. For Landsat scale accuracy assessment, independent plot samples collected across the study area during the same year as the training data and predictions were used (fig. 3). Potential locations for assessment plots were selected in two stages, and were restricted to landscapes below $3,100 \mathrm{~m}$ in elevation, on public land, within $1 \mathrm{~km}$ of a mapped
Table 1. Input layer number and type used to model components.

\begin{tabular}{|c|c|}
\hline Layer & Description \\
\hline 01 & May 30, 2008 Landsat 5, band 1 \\
\hline 02 & May 30, 2008 Landsat 5, band 2 \\
\hline 03 & May 30, 2008 Landsat 5, band 3 \\
\hline 04 & May 30, 2008 Landsat 5, band 4 \\
\hline 05 & May 30, 2008 Landsat 5, band 5 \\
\hline 06 & May 30, 2008 Landsat 5, band 6 \\
\hline 07 & May 30, 20083 Ratio Index band 1 \\
\hline 08 & May 30, 20083 Ratio Index band 2 \\
\hline 09 & May 30, 20083 Ratio Index band 3 \\
\hline 10 & June 15, 2008 Landsat 5, band 1 \\
\hline 11 & June 15, 2008 Landsat 5, band 2 \\
\hline 12 & June 15, 2008 Landsat 5, band 3 \\
\hline 13 & June 15, 2008 Landsat 5, band 4 \\
\hline 14 & June 15, 2008 Landsat 5, band 5 \\
\hline 15 & June 15, 2008 Landsat 5, band 6 \\
\hline 16 & June 15, 20083 Ratio Index band 1 \\
\hline 17 & June 15, 20083 Ratio Index band 2 \\
\hline 18 & June 15, 20083 Ratio Index band 3 \\
\hline 19 & October 3, 2007 Landsat 5, band 1 \\
\hline 20 & October 3, 2007 Landsat 5, band 2 \\
\hline 21 & October 3, 2007 Landsat 5, band 3 \\
\hline 22 & October 3, 2007 Landsat 5, band 4 \\
\hline 23 & October 3, 2007 Landsat 5, band 5 \\
\hline 24 & October 3, 2007 Landsat 5, band 6 \\
\hline 25 & October 3, 20073 Ratio Index band 1 \\
\hline 26 & October 3, 20073 Ratio Index band 2 \\
\hline 27 & October 3, 20073 Ratio Index band3 \\
\hline 28 & Aspect, 9 Direction \\
\hline 29 & Elevation, seven classes \\
\hline 30 & Slope Position Index \\
\hline 31 & Slope, Degrees \\
\hline 32 & May 30, 2008, June 15, 2008 Ratio Difference Index band 1 \\
\hline 33 & May 30, 2008, June 15, 2008 Ratio Difference Index band 2 \\
\hline 34 & May 30, 2008, June 15, 2008 Ratio Difference Index band 3 \\
\hline 35 & May30, 2008, October 3, 2007 Ratio Difference Index band 1 \\
\hline 36 & May 30, 2008, October 3, 2007 Ratio Difference Index band 2 \\
\hline 37 & May 30, 2008, October 3, 2007 Ratio Difference Index band 3 \\
\hline 38 & June 15, 2008, October 3, 2007 Ratio Difference Index band 1 \\
\hline 39 & June 15, 2008, October 3, 2007 Ratio Difference Index band 2 \\
\hline 40 & June 15, 2008, October 3, 2007 Ratio Difference Index band 3 \\
\hline
\end{tabular}




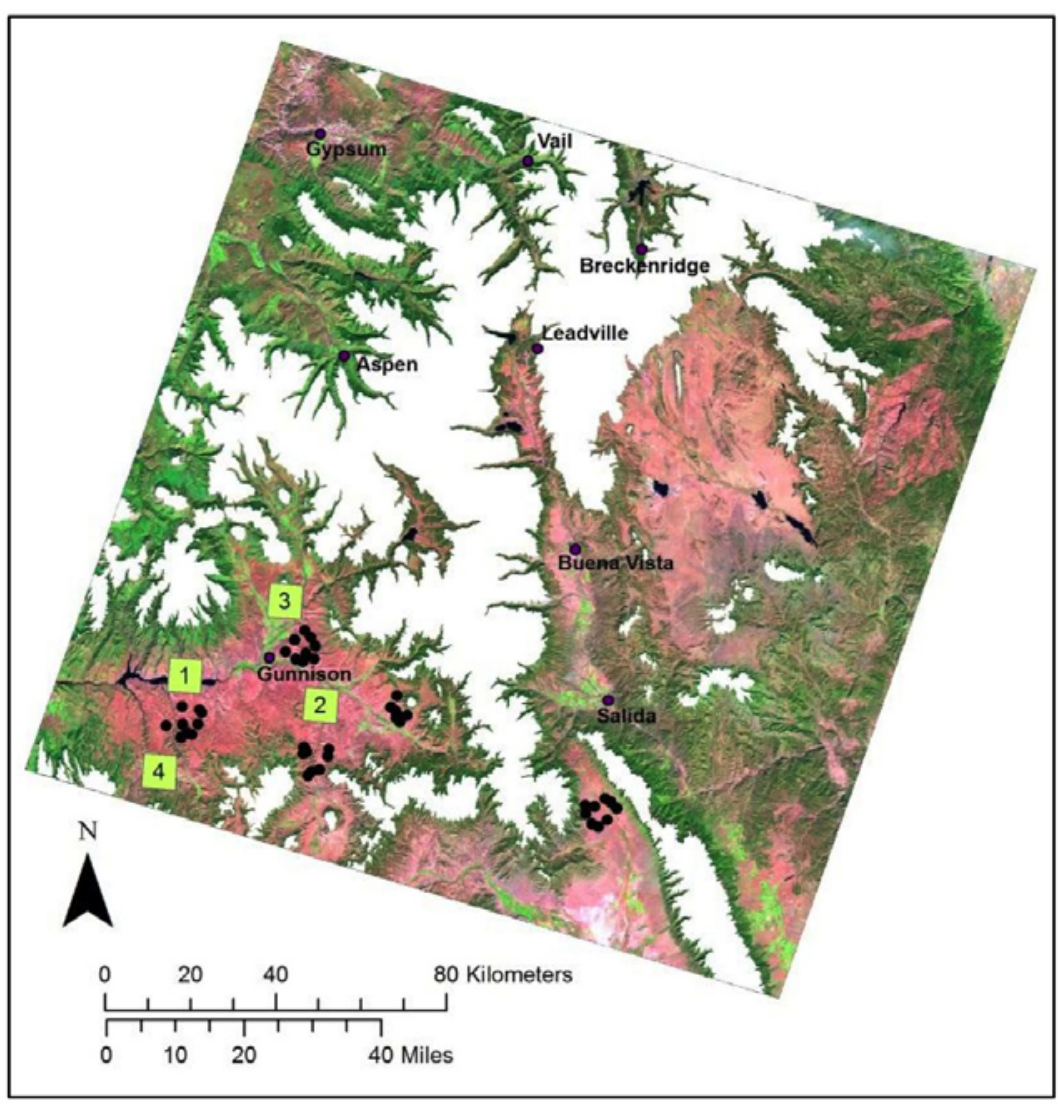

Figure 3. Location of the 41 sagebrush rangeland accuracy assessment plots across the Landsat path 34 row 33 study area focused on the Gunnison Basin, Colorado. The plots are in black and the higher elevation areas (greater than 3,100-m) are masked in white.

road or trail, and within the extent of the lumped shrub, grass, and barren classes in the U.S. National Land Cover Database 2001 (Homer and others, 2007). For the first stage, five 10-km selection circles randomly were located within the Gunnison Basin to focus field validation efforts. For the second stage, seven to nine plot locations occurring within each of the $10-\mathrm{km}$ circles randomly were selected from within the potential landscapes defined above. Evaluation plot sampling was completed using the same field protocols as those used for training plot data collection.

Independent accuracy assessment results are reported using the coefficient of determination $\left(\mathrm{R}^{2}\right)$, the root mean square error (RMSE), and the normalized root mean square error (NRMSE). RMSE represents an absolute measure of model fit and is in the same unit as the modeled variable. NRMSE is dimensionless and is calculated by dividing the RMSE by the range of observed values to allow comparisons among RMSE calculations for different variable predictions, and typically is expressed as a percentage.

\section{Results}

Continuous predictions for eight different sagebrushsteppe components at 2.4-m QuickBird and 30-m Landsat TM scales were generated (fig. 4). QuickBird results were generated across four $64-\mathrm{km}^{2}$ footprints in the Gunnison Basin,
Colorado. Landsat predictions were generated across the Path 34, Row 33 scene extent in south-central Colorado, which includes the Gunnison Basin.

Field sampling results: A total of 331 polygons were sampled in and around the Gunnison Basin, Colorado area during the summer of 2007. Vegetative characteristics at 290 sampled polygons across four QuickBird scenes were used for model development training data and QB model prediction evaluation. Sampling at an additional 41 randomly located plots was used to provide independent evaluation data for the Landsat $34 / 33$ study area model (fig. 3). Field collection of training data occurred on average within 26 days (5.49 standard error days) for all four sampled QB images (table 2).

Table 2. Comparison of QuickBird acquisitions versus field sampling dates.

\begin{tabular}{cc}
\hline Site & $\begin{array}{c}\text { Number of days between } \\
\text { QuickBird (OB) acquisition } \\
\text { and field measurement }\end{array}$ \\
\hline QB site 1 & 23 \\
QB site 2 & 12 \\
QB site 3 & 32 \\
QB site 4 & 37 \\
Average & 26 \\
\hline
\end{tabular}




\section{QuickBird 2.4 meter Landsat $\mathbf{3 0}$ meter}

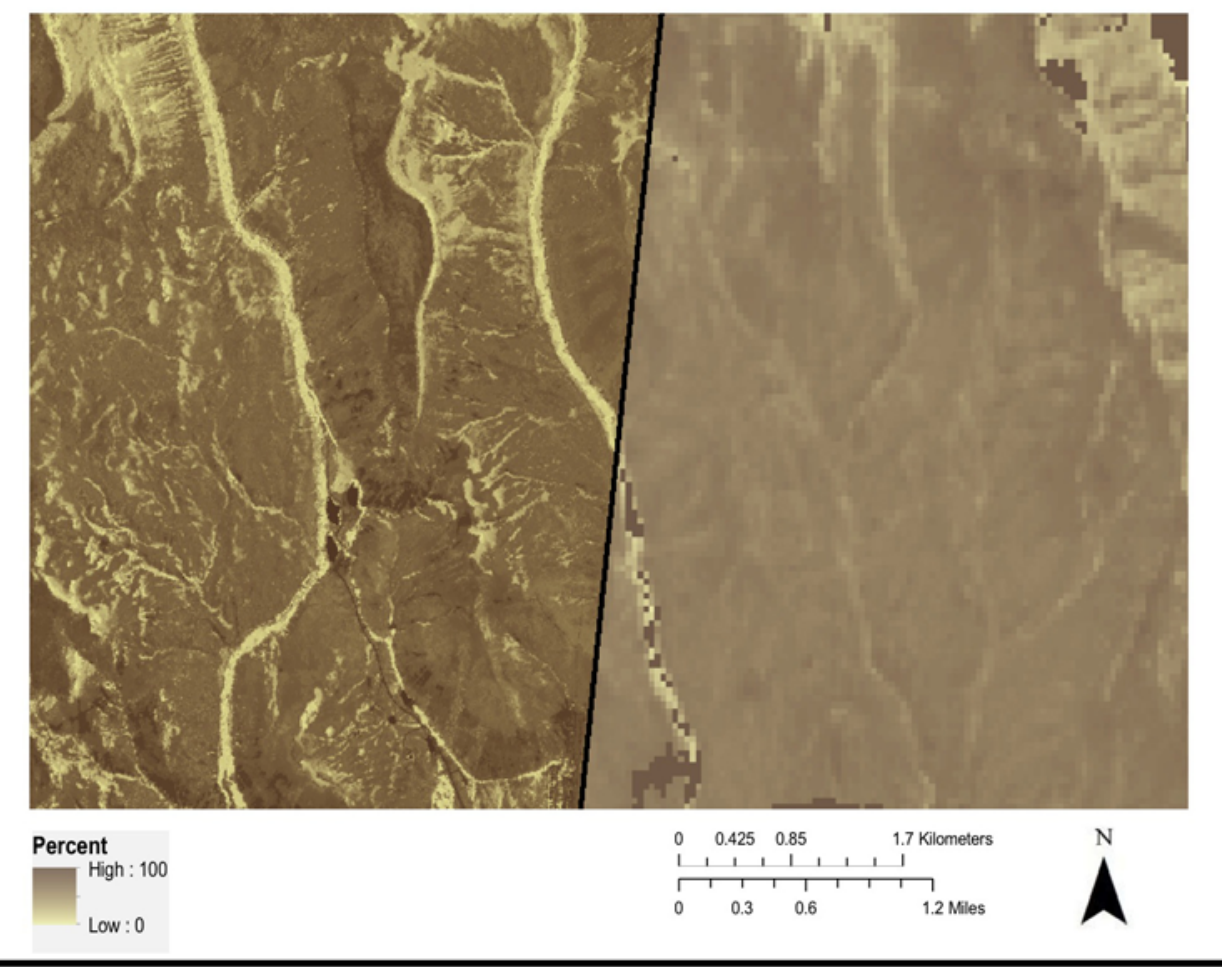

Figure 4. Example of percent bare ground predictions at two spatial scales, in QuickBird site 1 within the Gunnison Basin, Colorado.
Model predictions — QuickBird imagery: Predictions for all eight sagebrush-steppe components across each of the four QuickBird scenes were independently generated (fig. 5); but results are summarized across all four sites in table 3 . Accuracy assessment was based on the correlation of independent data with modeled predictions from a sample of plots withheld for validation. $\mathrm{R}^{2}$ values ranged from a low of 0.13 for Wyoming sagebrush (A.t. wyomingensis) to a high of 0.61 for bare ground (table 3 ). RMSE values ranged from 3.52 percent for big sagebrush (A. tridentata) to 10.82 percent for bare ground (table 3 ). Based on these RMSE results, a bare ground prediction of 20 percent from the model would typically range from 9.18 percent to 30.82 percent in measured results on the ground. A big sagebrush prediction of 20 percent from the model would typically range from 16.48 percent to 23.52 percent in measured results in the field (table 3). NRMSE values across all component QB predictions averaged 18 percent.

Model predictions - Landsat: Predictions for each of the eight rangeland components across the Landsat 34/33 study area were generated using Landsat TM 30-m imagery (fig. 6). Landsat component prediction accuracy results were determined using 41 validation plots sampled independently. $\mathrm{R}^{2}$ values across the 34/33 study area ranged from a low of 0.09 for herbaceous to a high of 0.45 for bare ground (table 3 ). RMSE values ranged across the $34 / 33$ study area ranged from 4.53 percent for Wyoming sagebrush cover to 12.44 percent for herbaceous cover (table 3). Based on these RMSE results at the full Landsat scene scale, an herbaceous prediction of 20 percent from the model would typically range from 7.56 percent to 32.44 percent in measured results on the ground, and a Wyoming sagebrush prediction of 20 percent from our model would typically range from 15.47 percent to 24.53 percent in measured results on the ground. NRMSE values for Landsat predictions averaged 22.9 percent, about 5 percent higher than QB predictions.

\section{Discussion}

These products potentially offer the most current (2012) rigorous large-area attempt for remote sensing quantification of sagebrush habitat across the Gunnison Basin, and provide the opportunity to develop more extensive sage-grouse habitat modeling than has previously been available. Project specific objectives and outcomes are discussed below.

Field sampling: The field sampling protocol strived to achieve a reasonable balance among scale, effort, access, and precision across all components. The sample site selection protocol using QuickBird (QB) segmentation was especially effective at optimizing field collection to maximize sampling of variation in spectral signatures, and it facilitated successful application to larger imagery scales. The average time (26 days) between the collection of the image and field sampling was phenolgically reasonable in this ecosystem, especially 


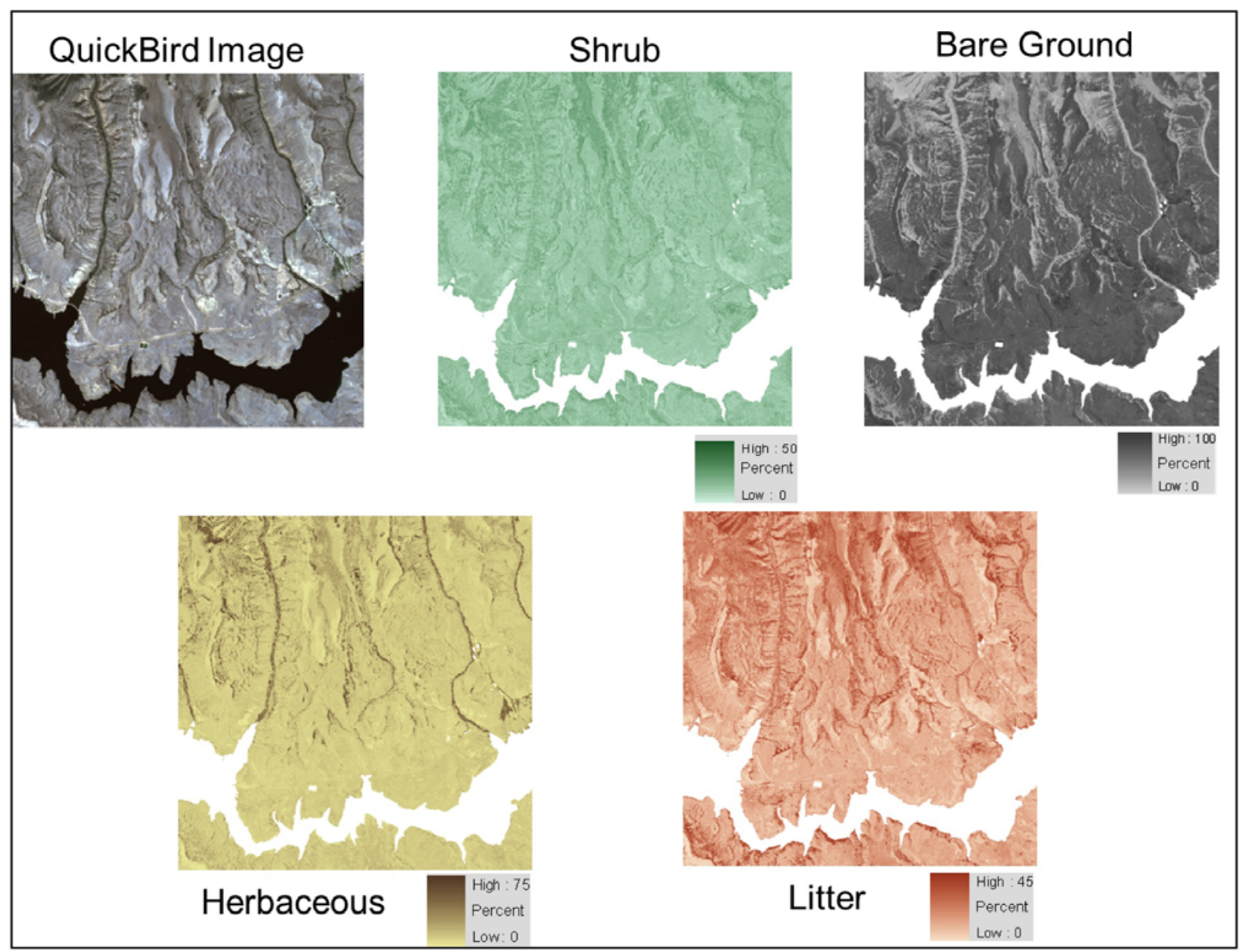

Figure 5. Example predictions for four primary sagebrush rangeland components from QuickBird imagery in QuickBird site 1 within the Gunnison Basin, Colorado. Elevations over 3,100 meters and nonsagebrush-steppe land covers are masked (white).

given the difficult logistical issues involved of synergizing field and image collection. The $1-\mathrm{m}^{2}$ quadrats used for cover measurements overall offered a reasonable method for reliable and consistent measurement of all components; however, steep topography provided access challenges for some plots, and the presence of trees in a few plots made optimal measurement more difficult.

Model prediction, QuickBird imagery: Based on the modeled results at the QB scale, the stratification and field sampling approaches successfully measured the range of variability of the rangeland components. Multispectral QB imagery proved to be a useful extrapolation medium for the field sampling. The 2.4-m pixel scale allowed the RT enough spatial area for sub-pixel estimates to be relevant while still maintaining high resolution. QB component predictions averaged across all four QB sites displayed a mean $\mathrm{R}^{2}$ value of 0.41 for all eight components, and a mean RMSE across the seven cover predictions of 5.95 percent. These results were not only adequate to support further spatial extrapolation of these results at Landsat scales, but also are comparable to QB results from a similar study conducted across the State of Wyoming (Homer and others, 2012).

Model prediction, Landsat: Coarse scale imagery such as Landsat offers an ideal medium to further extrapolate component models from the QB scales to larger landscapes. As expected, moving to a lower resolution, even with an increase in the number of input variables for the regression tree, did reduce the prediction confidence. The component predictions at the Landsat scale displayed a mean value of 0.25 for all eight components, and a mean RMSE across the seven cover predictions of 7.96. One cause for the loss of precision between Quickbird and Landsat scales is the Modifiable Areal Unit Problem (MAUP), where the mean value does not change but variance declines with increasing aggregation. Thus, the modeled range of a given variable becomes compressed as the spatial size of the pixel increases, for example, the total possible range of sagebrush canopy density decreases as patch size increases [see Homer and others (2012) for further discussion]. Overall, accuracies were comparable to similar 
Table 3. Accuracy assessment (AA) of all sagebrush rangeland variable predictions for each study area extent and sensor, from south-central Colorado.

[Root mean square error (RMSE) values are in the units of model prediction (percent cover or centimeters for shrub height)].

\begin{tabular}{|c|c|c|c|c|c|c|c|}
\hline Site & Sensor & Variable & $\mathbf{N}$ & $\mathbf{R}^{2}$ & RMSE & NRMSE & Type \\
\hline All Sites & Quickbird & Sage (percent) & 64 & 0.47 & 3.67 & 0.20 & Independent AA \\
\hline All Sites & Quickbird & Shrub (percent) & 64 & 0.19 & 5.10 & 0.20 & Independent AA \\
\hline All Sites & Quickbird & Herbaceous (percent) & 64 & 0.55 & 5.93 & 0.10 & Independent AA \\
\hline All Sites & Quickbird & Litter (percent) & 64 & 0.43 & 8.10 & 0.17 & Independent AA \\
\hline All Sites & Quickbird & Wyomingensis (percent) & 64 & 0.13 & 4.49 & 0.30 & Independent AA \\
\hline All Sites & Quickbird & Shrub (height) & 64 & 0.40 & 8.15 & 0.14 & Independent AA \\
\hline $\begin{array}{l}\text { COVER MEAN } \\
\text { (excluding shrub height) }\end{array}$ & & & & .41 & 5.95 & .19 & \\
\hline Site 1 & Quickbird & Herbaceous (percent) & 18 & 0.31 & 5.97 & 0.23 & Independent AA \\
\hline Site 1 & Quickbird & Litter (percent) & 18 & 0.45 & 5.23 & 0.28 & Independent AA \\
\hline Site 1 & Quickbird & Big sage (percent) & 18 & 0.29 & 3.15 & 0.29 & Independent AA \\
\hline Site 1 & Quickbird & Wyomingensis (percent) & 18 & 0.09 & 5.14 & 0.34 & Independent AA \\
\hline Site 1 & Quickbird & Shrub (height) & 18 & 0.59 & 7.61 & 0.19 & Independent AA \\
\hline Site 2 & Quickbird & Sage (percent) & 15 & 0.18 & 4.65 & 0.33 & Independent AA \\
\hline Site 2 & Quickbird & Shrub (percent) & 15 & 0.15 & 5.60 & 0.29 & Independent AA \\
\hline Site 2 & Quickbird & Bare (percent) & 15 & 0.18 & 10.18 & 0.36 & Independent AA \\
\hline Site 3 & Quickbird & Sage (percent) & 15 & 0.43 & 3.26 & 0.25 & Independent AA \\
\hline Site 3 & Quickbird & Shrub (percent) & 15 & 0.01 & 4.60 & 0.42 & Independent AA \\
\hline Site 3 & Quickbird & Bare (percent) & 15 & 0.43 & 13.93 & 0.24 & Independent AA \\
\hline Site 3 & Quickbird & Herbaceous (percent) & 15 & 0.93 & 3.71 & 0.07 & Independent AA \\
\hline Site 3 & Quickbird & Litter (percent) & 15 & 0.06 & 11.32 & 0.32 & Independent AA \\
\hline Site 3 & Quickbird & Big sage (percent) & 15 & 0.65 & 3.45 & 0.19 & Independent AA \\
\hline Site 3 & Quickbird & Wyomingensis (percent) & 15 & 0.01 & 5.05 & 0.46 & Independent AA \\
\hline Site 3 & Quickbird & Shrub (height) & 15 & 0.26 & 10.2 & 0.35 & Independent AA \\
\hline Site 4 & Quickbird & Sage (percent) & 16 & 0.28 & 3.72 & 0.37 & Independent AA \\
\hline Site 4 & Quickbird & Shrub (percent) & 16 & 0.01 & 6.98 & 0.29 & Independent AA \\
\hline Site 4 & Quickbird & Bare (percent) & 16 & 0.80 & 9.97 & 0.14 & Independent AA \\
\hline Site 4 & Quickbird & Herbaceous (percent) & 16 & 0.06 & 7.47 & 0.39 & Independent AA \\
\hline
\end{tabular}


Table 3. Accuracy assessment (AA) of all sagebrush rangeland variable predictions for each study area extent and sensor, from south-central Colorado.-Continued

[Root mean square error (RMSE) values are in the units of model prediction (percent cover or centimeters for shrub height)].

\begin{tabular}{llllrrrr}
\hline \multicolumn{1}{c}{ Site } & Sensor & \multicolumn{1}{c}{ Variable } & N & $\mathbf{R}^{2}$ & RMSE & NRMSE & Type \\
\hline Site 4 & Quickbird & Litter (percent) & 16 & 0.63 & 8.63 & 0.18 & Independent AA \\
Site 4 & Quickbird & Big sage (percent) & 16 & 0.37 & 3.40 & 0.34 & Independent AA \\
Site 4 & Quickbird & Wyomingensis (percent) & 16 & 0.00 & 3.14 & 0.79 & Independent AA \\
Site 4 & Quickbird & Shrub (height) & 16 & 0.45 & 8.72 & 0.17 & Independent AA \\
& & & & & & & \\
Path/Row 34/33 & Landsat & Sage (percent) & 41 & 0.19 & 6.18 & 0.24 & Independent AA \\
Path/Row 34/33 & Landsat & Shrub (percent) & 41 & 0.25 & 6.51 & 0.23 & Independent AA \\
Path/Row 34/33 & Landsat & Bare (percent) & 41 & 0.45 & 12.41 & 0.17 & Independent AA \\
Path/Row 34/33 & Landsat & Herbaceous (percent) & 41 & 0.09 & 12.44 & 0.32 & Independent AA \\
Path/Row 34/33 & Landsat & Litter (percent) & 41 & 0.26 & 7.98 & 0.21 & Independent AA \\
Path/Row 34/33 & Landsat & Big sage (percent) & 41 & 0.17 & 6.03 & 0.23 & Independent AA \\
Path/Row 34/33 & Landsat & Wyomingensis (percent) & 41 & 0.21 & 4.53 & 0.23 & Independent AA \\
Path/Row 34/33 & Landsat & Shrub (height) & 41 & 0.35 & 7.61 & 0.20 & Independent AA \\
COVER MEAN & & & & .23 & 8.01 & .23 & \\
(excluding shrub height) & & & & & & & \\
\hline
\end{tabular}

\section{Gunnison Basin}

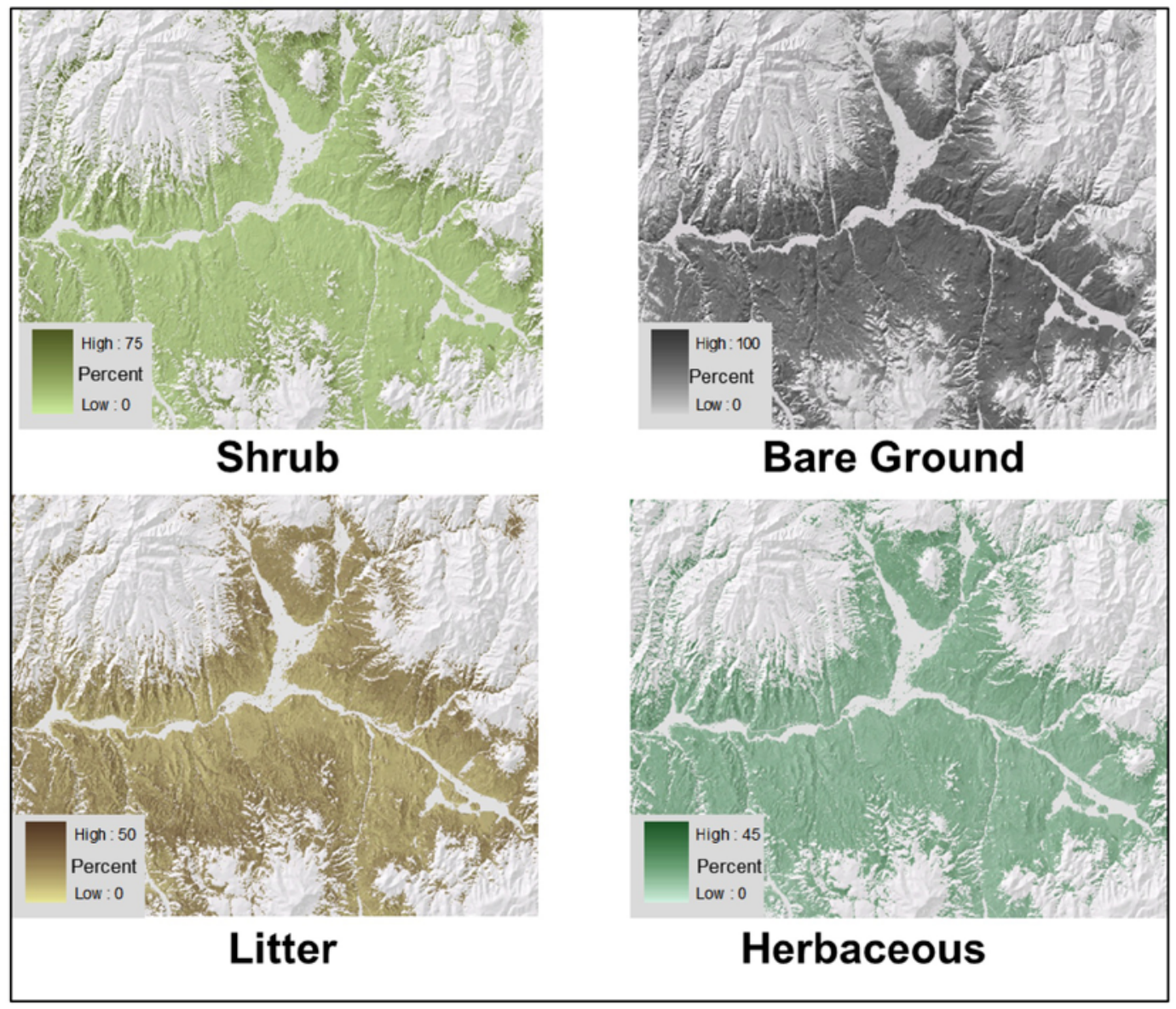

Figure 6. Example predictions for four primary components from Landsat (30-meter) imagery in the Gunnison Basin, Colorado. Elevations more than 3,100 meters and nonsagebrushsteppe land covers are masked (white). 
work already done in Wyoming (Homer and others, 2012). We caution users that although Landsat prediction products were extrapolated within the full area of path/row 34/33 (including areas outside of the Gunnison Basin), products were not calibrated for areas outside the Gunnison Basin and should be used with caution in those areas.

Project products demonstrate that significant incremental methodological improvements can be made in sagebrushsteppe habitat classification using remote sensing in the Gunnison Basin. These results offer significant improvement to sagebrush habitat quantification at multiple scales and offer users products that have been validated. The approach of using pre-sampling segmentation and landscape stratification, detailed ground sampling, and regression tree modeling of components resulted in reliable component predictions that offer sufficient RMSE accuracies to provide baseline products for a variety of potential applications. These methods have been specifically developed to be both operational and cost effective over large areas, enabling potential re-measurement to support future change monitoring. These modeled components can now provide maximum flexibility to users at various scales and for a wide variety of applications. Further refinement of these remote sensing component predictions in the future is possible, likely by focusing on more extensive ground plot sampling, employing new high and moderate-resolution satellite sensors that offer additional spectral bands for vegetation discrimination, and capturing more dates of satellite imagery to better represent phenological variation.

\section{Acknowledgments}

We thank Greg Wann and Lorie Brummer for their dedicated efforts in conducting field sampling, and Theresa Childers and Dan Neubaum for assisting with the coordination of field sampling efforts.

Funding for this research was provided by the U.S. Geological Survey, Fort Collins Science Center, Black Canyon of the Gunnison National Park, Curecanti National Recreation Area, the U.S. Geological Survey Natural Resources Preservation Program, National Park Service Challenge Cost Share Program, and the Rocky Mountain Cooperative Ecosystem Studies Unit. We also thank the Gunnison sage-grouse Strategic Committee for their interest in our research and support in seeing these products developed.

\section{References Cited}

Aldridge, C.L., Saher, D.J., Childers, T., Stahlnecker, K.E., and Bowen, Z.H., 2012, Crucial nesting habitat for Gunnison sage-grouse - A spatially explicit hierarchical approach: Journal of Wildlife Management, v. 76, p. 391-406.
Anderson, A., and McCuistion, K.C., 2008, Evaluating strategies for ranching in the 21 st century-Successfully managing rangeland for wildlife and livestock: Rangelands, v. 30, p. $8-14$.

Chander, G., Huang, C., Yang, L., Homer, C., and Larson, C., 2009, Developing consistent landsat data sets for large area applications - The MRLC 2001 protocol: IEEE Geoscience and Remote Sensing Letters, v. 6, no. 4, p. 777-781.

Connelly, J.W., Knick, S.T., Schroeder, M.A., and Stiver, S.J., 2004, Conservation assessment of greater sage-grouse and sagebrush habitats: Cheyenne, Wyoming, Western Association of Fish and Wildlife Agencies, Unpublished Report, $610 \mathrm{p}$.

Colorado Water Conservation Board (CWCB), 2009, 2050 population projections for the State of Colorado municipal and industrial water use projections: Camp Dresser and McKee Inc. and Harvey Economics, 244 p., accessed May 28, 2010, at http://cwcb.state.co.us/IWMD/ COsWaterSupplyFuture.

Davies, K.W., Bates, J.D., and Miller, R.F., 2007, Environmental and vegetation relationships of the Artemisia tridentata spp. wyomingensis alliance: Journal of Arid Environments, v. 70, p. 478-494.

Gunnison Sage-Grouse Rangewide Steering Committee (GSGRSC), 2005, Gunnison sage-grouse rangewide conservation plan: Denver, Colorado, Colorado Division of Wildlife, 5 p.

Homer, C., Dewitz, J., Fry, J., Coan, M., Hossain, N., Larson, C., Herold, N., McKerrow, A., VanDriel, J.N., and Wickham, J., 2007, Completion of the 2001 National Land Cover Database for the conterminous United States: Photogrammetric Engineering and Remote Sensing, v. 73, 337-341.

Homer, C.G., Aldridge, C.A., Meyer, D.K., and Schell, S.J., 2012, Multi-scale remote sensing sagebrush characterization with regression trees over Wyoming, USA-Laying a foundation for monitoring: International Journal of Applied Earth Observation and Geoinformation, v. 14, no. 1, p. 233-244.

Homer, C.G., Aldridge, C.L., Meyer, D.K., Coan, M.J., and Bowen, Z.H., 2008, Multiscale sagebrush rangeland habitat modeling in southwest Wyoming: U.S. Geological Survey Open-File Report 2008-1027, 14 p.

Oyler-McCance, S. J., Burnham, K.P., and Braun, C.E., 2001, Influence of changes in sagebrush on Gunnison sage grouse in southwestern Colorado: Southwestern Naturalist, v. 46, p. 323-331.

Quinlan, J.R., 1993, C4.5 programs for machine learning: San Mateo, California, Morgan Kaufmann Publishers, 108 p. 
Rollins, M.G., 2009, LANDFIRE-A nationally consistent vegetation, wildland fire, and fuel assessment: International Journal of Wildland Fire, v. 18, no. 3, p. 235-249.

Schroeder, M.A., Aldridge, C.L., Apa, A.D., Bohne, J.R., Braun, C.E., Bunnell, D., Connelly, J.W., Deibert, P., Gardner, S.C., Hilliard, M.A., McAdam, S.M., Kobriger, G.D., McCarthy, C.W., McCarthy, J.J., Mitchell, D.L., Rickerson, E.V., and Stiver, S.J., 2004, Distribution of sage-grouse in North America: Condor, v. 106, p. 363-376.
Schrupp, D.L., Reiners, W.A., Thompson, T.G., O’Brien, L.E., Kindler, J.A., Wunder, M.B., Lowsky, J.F., Buoy, J.C., Satcowitz, L., Cade, A.L., Stark, J.D., Driese, K.L., Owens, T.W., Russo, S.J., and D’Erchia, F., 2000, Colorado gap analysis program - A geographic approach to planning for biological diversity — Final Report: Denver, Colorado, U.S. Geological Survey Biological Resources Division, Gap Analysis Program and Colorado Division of Wildlife, 816 p.

Publishing support provided by:

Rolla Publishing Service Center

For more information concerning this publication, contact:

U.S. Geological Survey Earth Resources Observation

and Science (EROS) Center

47914 252nd Street

Sioux Falls, South Dakota 57198

(605) 594-6151

Or visit the EROS Center Web site at:

http://eros.usgs.gov/ 



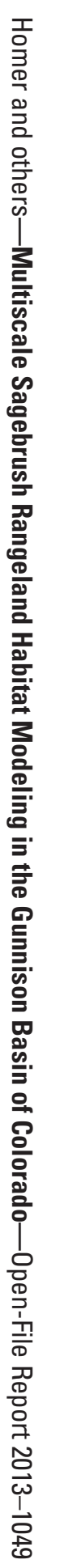

